\title{
Comparative study of soil properties and vegetation at various open dump and non-dumpsites in the Bengaluru city of Karnataka, India
}

\author{
Johny Joseph* \\ Department of Botany, Bharathiar University, Coimbatore-641046 (Tamil Nadu), India \\ Jayaram Reddy \\ Department of Botany, St. Joseph's Post Graduate Centre, Bengaluru-560027 \\ (Karnataka), India

\section{Sayantan} \\ Department of Life Sciences, CHRIST (Deemed to be University), Hosur Road, \\ Bengaluru- 560029 (Karnataka), India \\ *Corresponding author. E-mail:johny.joseph@christuniversity.in
}

\begin{abstract}
A comparative field studies on seven municipal dumpsites namely Agara $1\left(12.917^{\circ} \mathrm{N}\right.$ $\left.77.639^{\circ} \mathrm{E}\right)$, Agara $2\left(12.922^{\circ} \mathrm{N}, 77.639^{\circ} \mathrm{E}\right)$, HSR depot $\left(12.919^{\circ} \mathrm{N}, 77.644^{\circ} \mathrm{E}\right)$, Koramangala Church $\left(12.934^{\circ} \mathrm{N}, 77.626^{\circ} \mathrm{E}\right)$, Koramanagla BDA $\left(12.931^{\circ} \mathrm{N}, 77.625^{\circ} \mathrm{E}\right)$, Garvebhayipalya $\left(12.897^{\circ} \mathrm{N}, 77.638^{\circ} \mathrm{E}\right)$ and Sanjay Gandhi hospital $\left(12.891^{\circ} \mathrm{N}, 77.601^{\circ}\right.$ $\mathrm{E})$, and its adjoining non-dump sites were conducted to understand their soil characteristic features and the vegetation pattern. Soil characteristics were presented in terms of the physicochemical parameters and the vegetation patterns were presented in terms of the dominance using the ecological parameter Important Value Index (IVI). Soils at the dump sites showed higher mean electrical conductivity and $\mathrm{pH}$ values as compared to the nondump sites. Though the mineral content showed higher mean value in the dump sites (except chloride), there is no significant variation in the higher total soluble solutes between dump and non-dump sites $(P>0.05)$ As per ANNOVA there was highly significant variation in the heavy metal content between dump and non dumpsites $(P<0.01)$.. With respect to vegetation analysis though 50 different species found across locations only 10 species viz Alternatheria sessile, Amaranthus spinose, Caesalpinia pulcherima, Ipomea acumilanata, Ipomea evolvulus, Parthenium hysterophorous Pisum sativum, Ricinis communis, Sida rombifolia and Solanum lycopersicum were found consistent across all locations irrespective of the seasons. Among these, A. sessile, R. communis and A. spinosa were found dominant based on the IVI values across seven locations which further can be studied for their potential for phyto remediating the land pollutants such as heavy metals.
\end{abstract}

Keywords: ANOVA, dominant species, physicochemical characteristics, species diversity

\section{INTRODUCTION}

Management of urban municipal solid waste (MSW) generated from the human activity is a big challenge in most of the developing countries. Human settlements, small industries and commercial activities are the source of Urban MSW (Singh et al., 2011). Dumping of Hospitals wastes poses a serious health threat (Pattnaik and Reddy 2010). These threats, with inadequate litigable and legislative measures, are even more pronounced in developing countries where large quantity of solid wastes are haphazardly dumped, without robust contingency planning, thereby infringing on the quality of certain sensitive environmental resources such as air, soil, water and veg-

\section{Article Info}

DOI: 10.31018/jans.v11i1.1968

Received: December 18, 2018

Revised: January 30, 2019

Accepted: February 5, 2019

\section{How to Cite}

Joseph, J. et al. (2019). Comparative study of soil properties and vegetation at various open dump and non-dump sites in the Bengaluru city of Karnataka, India. Journal of Applied and Natural Science, 11 (1): $76-87$ 
ter pollution. Waste management has become very much important with the increase in population.

Waste dumpsites with various leachates of wastes are rich in organic and inorganic pollutants which lead to the growth of different varieties of plants (Calli 2005). When compared with normal sites, not all varieties of plants grow in waste disposal sites. In some countries like Nigeria, these waste dumping sites are used for cultivation as these sites also contain decayed and composted wastes which enhance soil fertility (Opaluwa et al., 2012). Plants grown on a land polluted with municipal, domestic or industrial wastes can absorb heavy metals in the form of mobile ions present in the soil through their roots These absorbed metals get bioacumulated in the roots, stems, fruits, grains and leaves of plants (Opaluwa et al., 2012; Zennaro et al., 2005). Such plants might be phytoremediators and are adaptive to grow in dumpsites or have other properties which are helpful in environmental studies. The growth of plants may vary with soil physicochemical properties like $\mathrm{pH}$, alkalinity, electrical conductivity, mineral composition and heavy metal content.

The objective of the present study was to analyse the soil physicochemical properties as well as the vegetation in the dump and non dumpsites across various locations in the Bengaluru city of India.

\section{MATERIALS AND METHODS}

Sites of the study: Around 300 dumpsites in the city of Bengaluru were visited, and out of which, seven of them were selected on random basis for the current study. These were Agara $1\left(12.917^{\circ}\right.$ $\left.\mathrm{N}, 77.639^{\circ} \mathrm{E}\right)$, Agara $2\left(12.922^{\circ} \mathrm{N}, 77.639^{\circ} \mathrm{E}\right)$, HSR depot $\left(12.919^{\circ} \mathrm{N}, 77.644^{\circ} \mathrm{E}\right)$, Koramangala Church $\left(12.934^{\circ} \mathrm{N}, 77.626^{\circ} \mathrm{E}\right)$, Koramanagla BDA $\left(12.931^{\circ} \mathrm{N}, 77.625^{\circ} \mathrm{E}\right)$, Garvebhayipalya (12.897 $\left.\mathrm{N}, 77.638^{\circ} \mathrm{E}\right)$ and Sanjay Gandhi hospital $\left(12.891^{\circ} \mathrm{N}, 77.601^{\circ} \mathrm{E}\right)$ dumpsites. Geographical coordinates and satellite image of these dumpsites are presented in Fig. 1 and profile of the dumpsites is summarized in Table 1.

Soil sampling and analysis: Surface soil samples were collected from 15 different points randomly distributed over each sampling area. Surface litter on the soil was first removed followed by the insertion of the sampling auger to a depth of $15 \mathrm{~cm}$ to collect the soil samples The collected samples were brought to the laboratory in acid rinsed plastic bottles (Poly lab India).

The samples were then tested for various physicochemical characteristics such as such as $\mathrm{pH}$, electrical conductivity, total soluble salts, calcium, magnesium, alkalinity, nitrates, sodium, sulphates, nitrogen, potassium and phosphorus as per the standard procedures (DAC 2011; USDA 2011). For the heavy metal analysis $(\mathrm{Co}, \mathrm{Cr}, \mathrm{Cu}, \mathrm{Fe}, \mathrm{Mn}$, $\mathrm{Ni}, \mathrm{Zn}$ and $\mathrm{Pb}$ ), soil samples were first digested using hydrofluoric acid (USEPA 1983), followed by their estimation using inductively coupled plasma atomic emission spectrometry (ICP-AES; JY HROOBA 2000 France)

Vegetation sampling and analysis: The abundance of vegetation was recorded at each site using Quadrat method (Kent 2011) two times viz during summer of the year 2015 and the spring of the year 2016.Using ribbon, transects were marked at the site, in parallel manner. With the help of ribbon and 4 pointers quadrats of the definite size $(1 \mathrm{~m} \times 1 \mathrm{~m})$ were laid down in each transect in the field. The different species present in each quadrat of each transect were listed down. The data was tabulated and different parameters such as density, dominance and frequency values for each species. were determined. Density refers to the number of individuals per unit area. Dominance refers to the basal area or crown coverage per unit area. Frequency refers to the fraction of sample plots containing the species. For particular species, these values may be expressed either in an absolute form or in a relative form. Relative values for density, dominance and frequency may be combined into a single factor called Importance Value Index (IVI), which reflects these three different measures of the importance of the species in the community. These various vegetation distribution measurements were determined according to the following formula.

$$
\begin{aligned}
& \text { Density }=\frac{\text { Number of mantawals }}{\text { Areasampled }} \\
& \text { Relative Density }=\frac{\text { Density for a apectes }}{\text { Total density for all species }} \times 100 \\
& \text { Dominance }=\frac{\text { Total of oasal area }}{\text { Area sampled }} \\
& \text { Relative Dominance }=\frac{\text { Domanance for aspectes }}{\text { Total dominance for all species }} \times 100 \\
& \text { Frequency }=\frac{\text { Number of plots in when spectes ocewrs }}{\text { Total number of plots sampled }} \\
& \text { Relative Frequency }=\frac{\text { Evequencyvaine for a spenes }}{\text { Total of frquencyvalues for all specises }} \times 100
\end{aligned}
$$

Statistical analysis: For physiochemical characteristics and the heavy metal concentration, the ANNOVA was performed on three sources of variation viz across the locations $(n=7)$, across the sites $(n=2)$ and across the location and the sites together. For the vegetation analysis, the ANNOVA was performed on the basis of six different sources of variations namely across (1) locations (2) sites (3) seasons (4) locations and sites together (5) sites and seasons together (6) locations and seasons together.

\section{RESULTS AND DISCUSSION}


Joseph, J. et al. / J. Appl. \& Nat. Sci. 11(1): 76- 87 (2019)

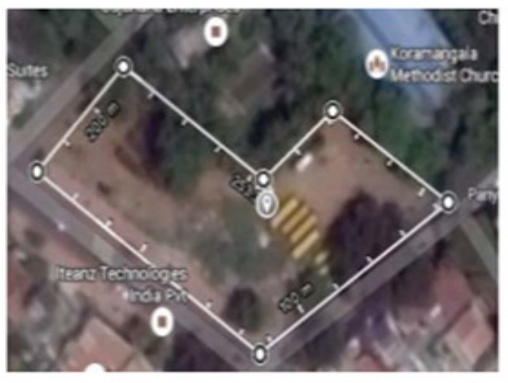

Koramangala Church Dum Location: $12.934,77.626$

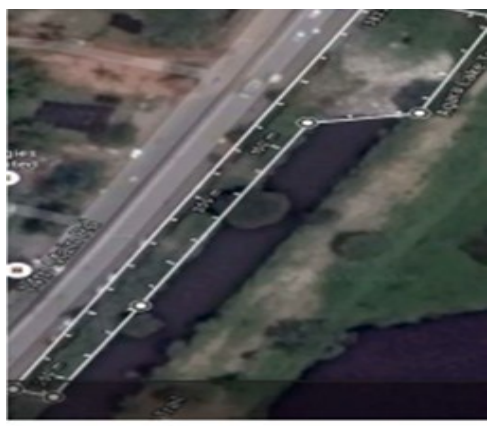

Agara Dumpsite 2

Location: $12.922,77.6390$

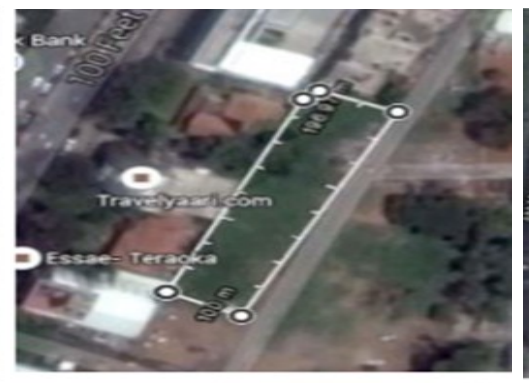

Koramangala BDA Dumps
Location: $12.931,77.625$

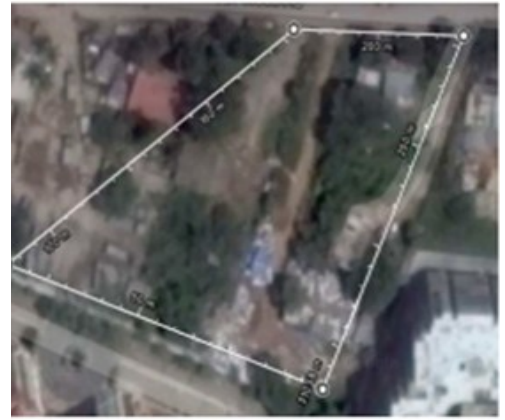

HSR Dumpsite

Location: $12.919,77.644$

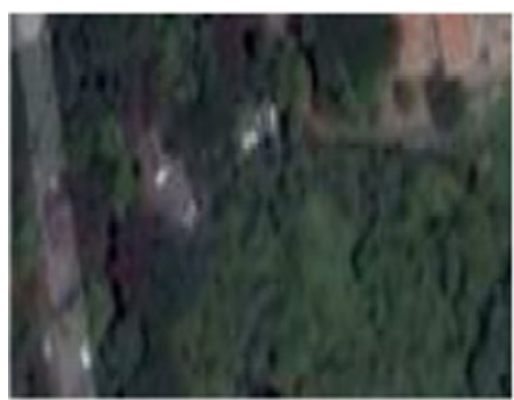

Sanjay Gandhi Hospital Road Dumpsite

Location: 12.891. 77.601

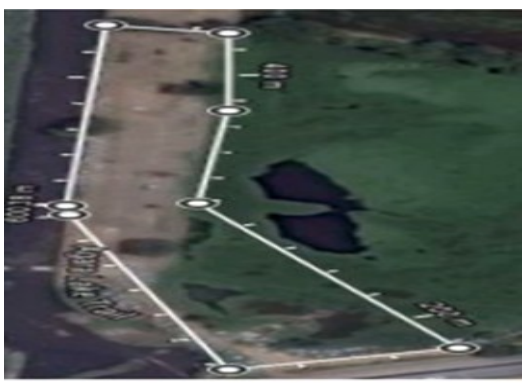

Agara Dumpsite 1

Location: $12.917,77.639$

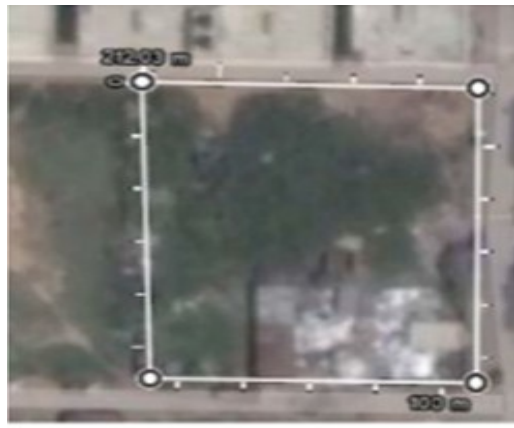

Garvebhavipalya Dumpsite

Location: $12.897,77.638$

Fig. 1. Aerial images and geographical coordinates of dump sites (Source :Survey of India,Koramangala,Bengaluru).
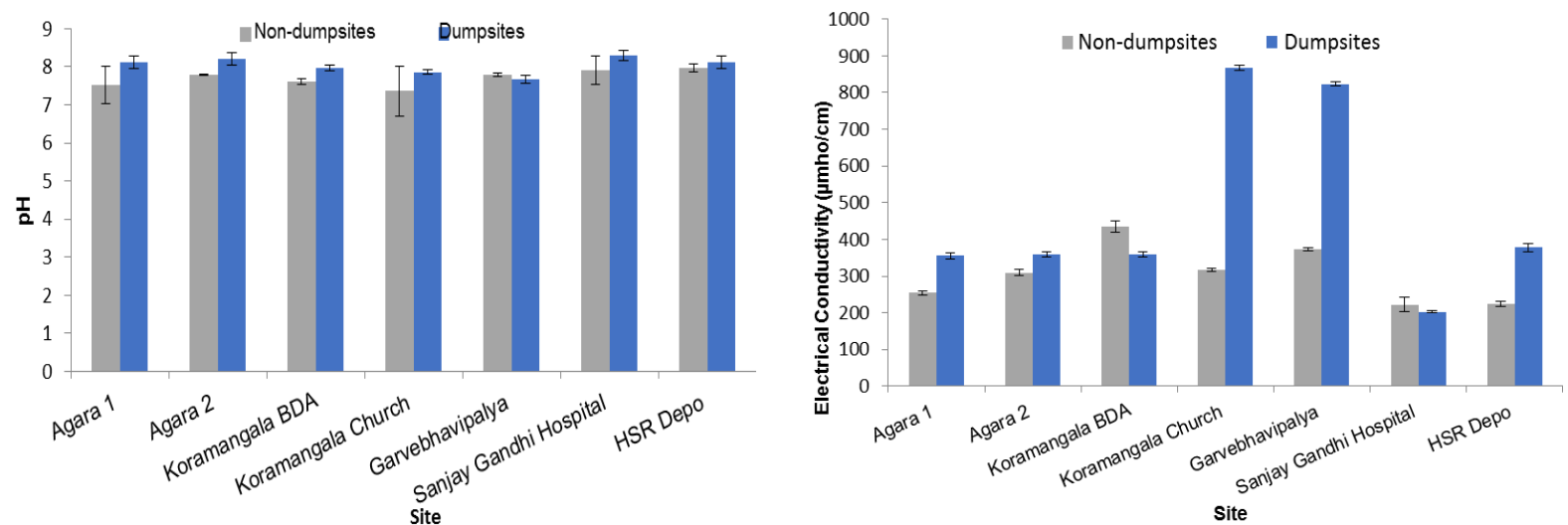

Fig. 2 (a) pH and (b) Electrical conductivity $(\mu \mathrm{mho} / \mathrm{cm})$ of soils of non-dumpsites and dumpsites. 
Joseph, J. et al. / J. Appl. \& Nat. Sci. 11(1): 76- 87 (2019)
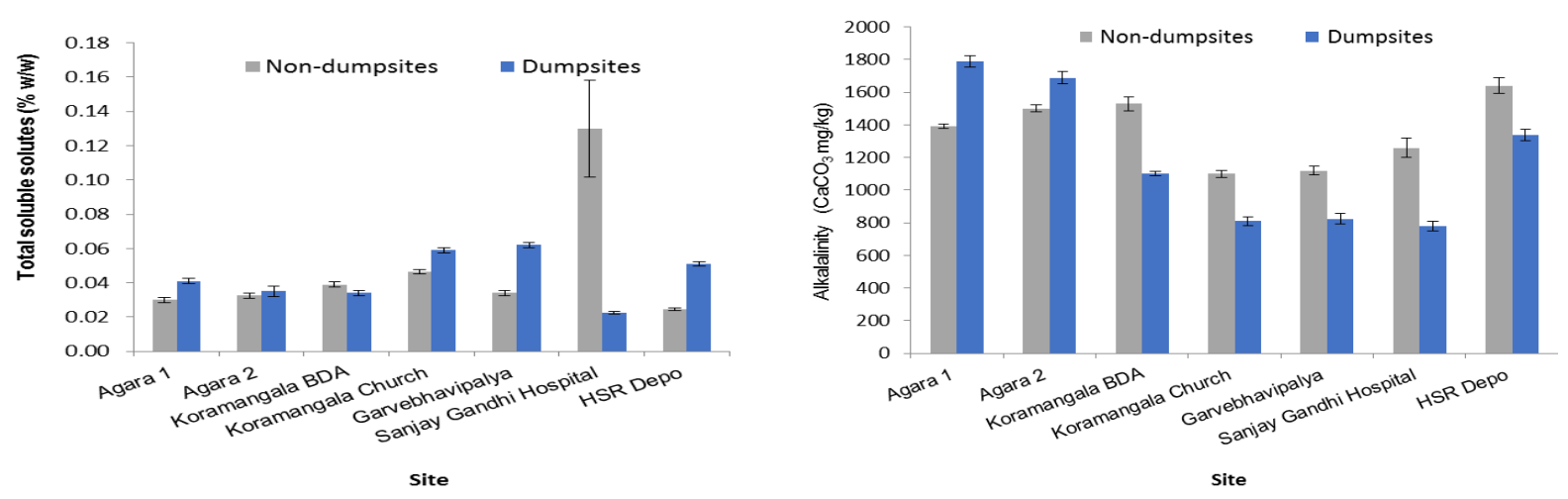

Fig. 3 (a) Total soluble solutes and (b) alkalinity $\left(\mathrm{CaCO}_{3} \mathrm{mg} / \mathrm{kg}\right)$ of soils of non-dump and dump sites.
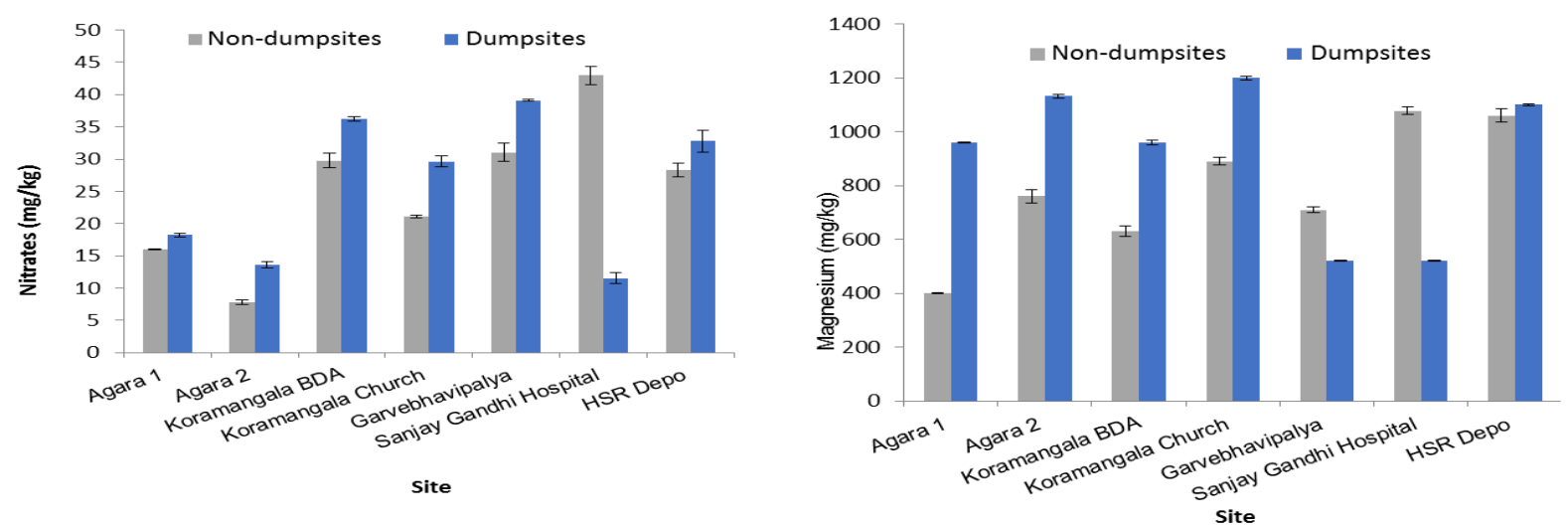

Fig. 4 (a) Nitrates and (b) magnesium ( $\mathrm{mg} / \mathrm{kg}$ ) of soils of non-dump and dumpsites.
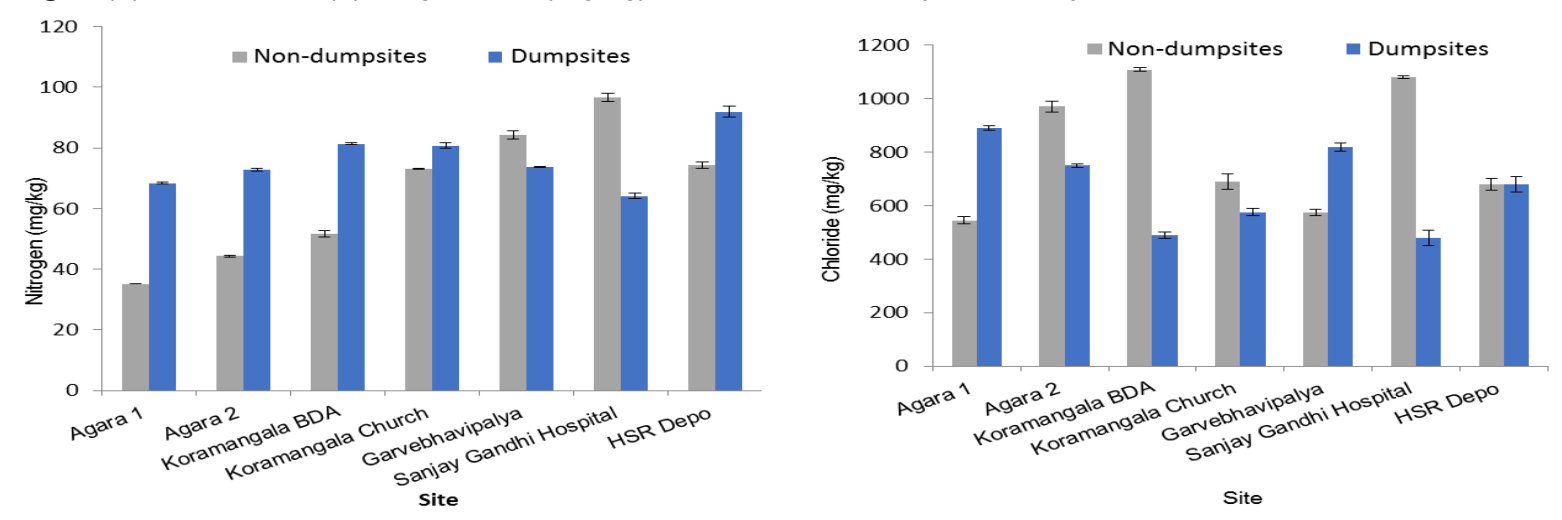

Fig. 5 (a) Nitrogen and (b) chloride ( $\mathrm{mg} / \mathrm{kg}$ ) of soils of non-dump and dumpsites.
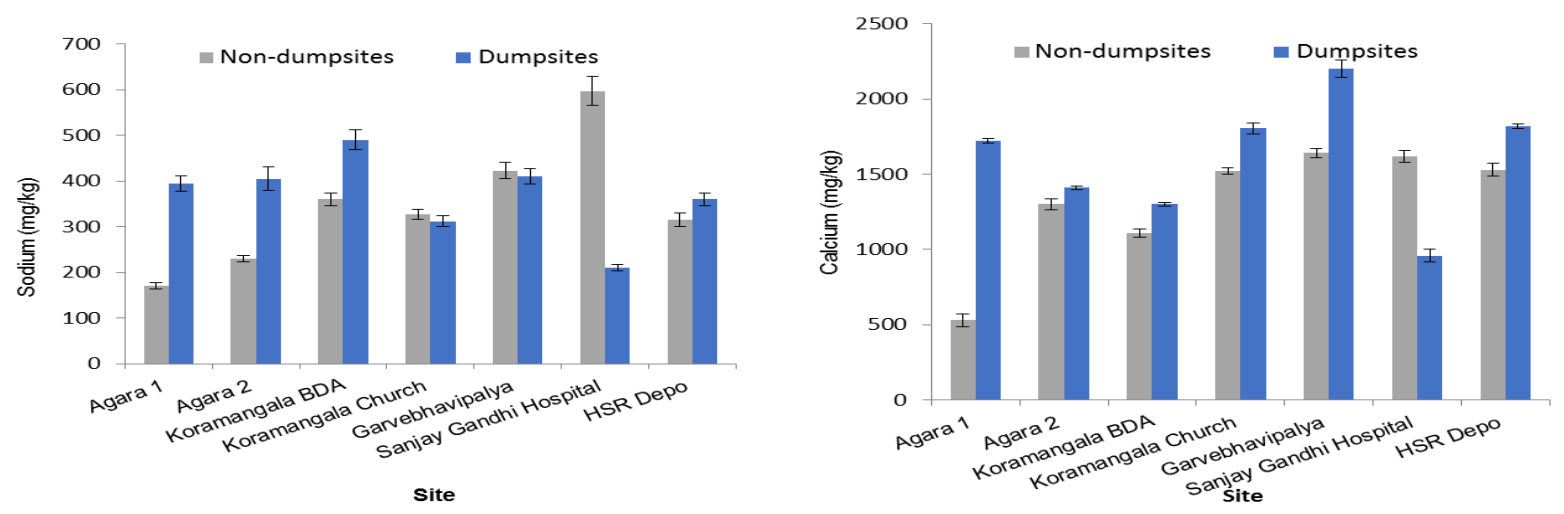

Fig. 6 (a) Sodium and (b) calcium ( $\mathrm{mg} / \mathrm{kg}$ ) of soils of non-dump and dumpsites. 
Joseph, J. et al. / J. Appl. \& Nat. Sci. 11(1): 76- 87 (2019)
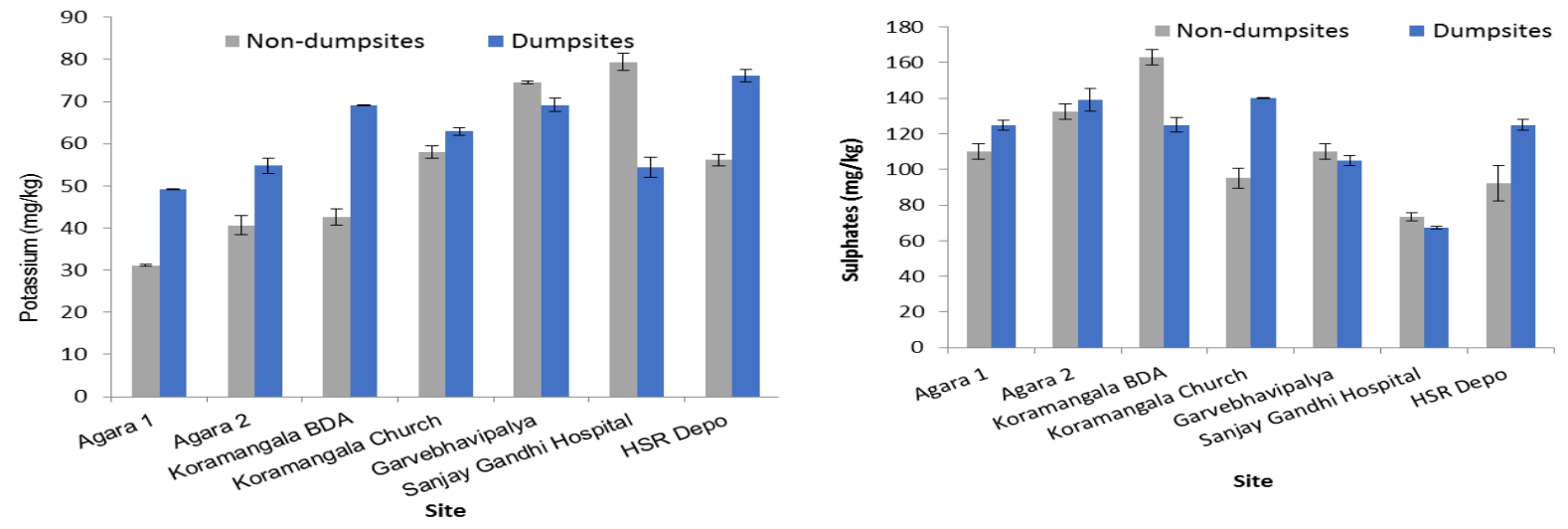

Fig. 7 (a) Potassium and (b) sulphate ( $\mathrm{mg} / \mathrm{kg}$ ) of soils of non-dump and dumpsites.

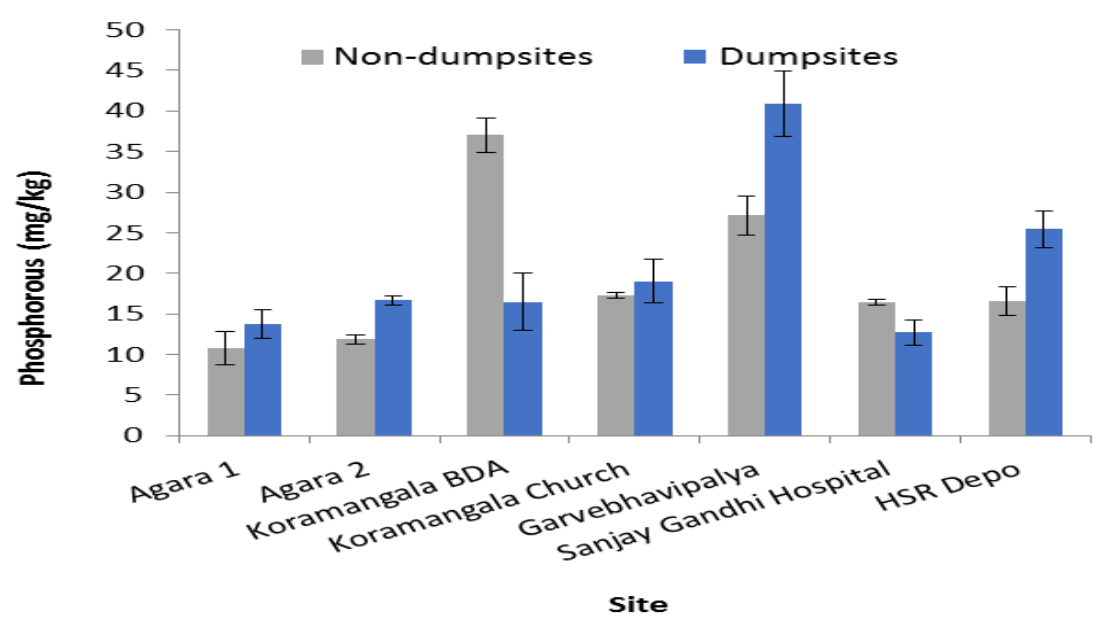

Fig. 8 Phosphorous ( $\mathrm{mg} / \mathrm{kg}$ ) of soils of non-dump and dumpsites.
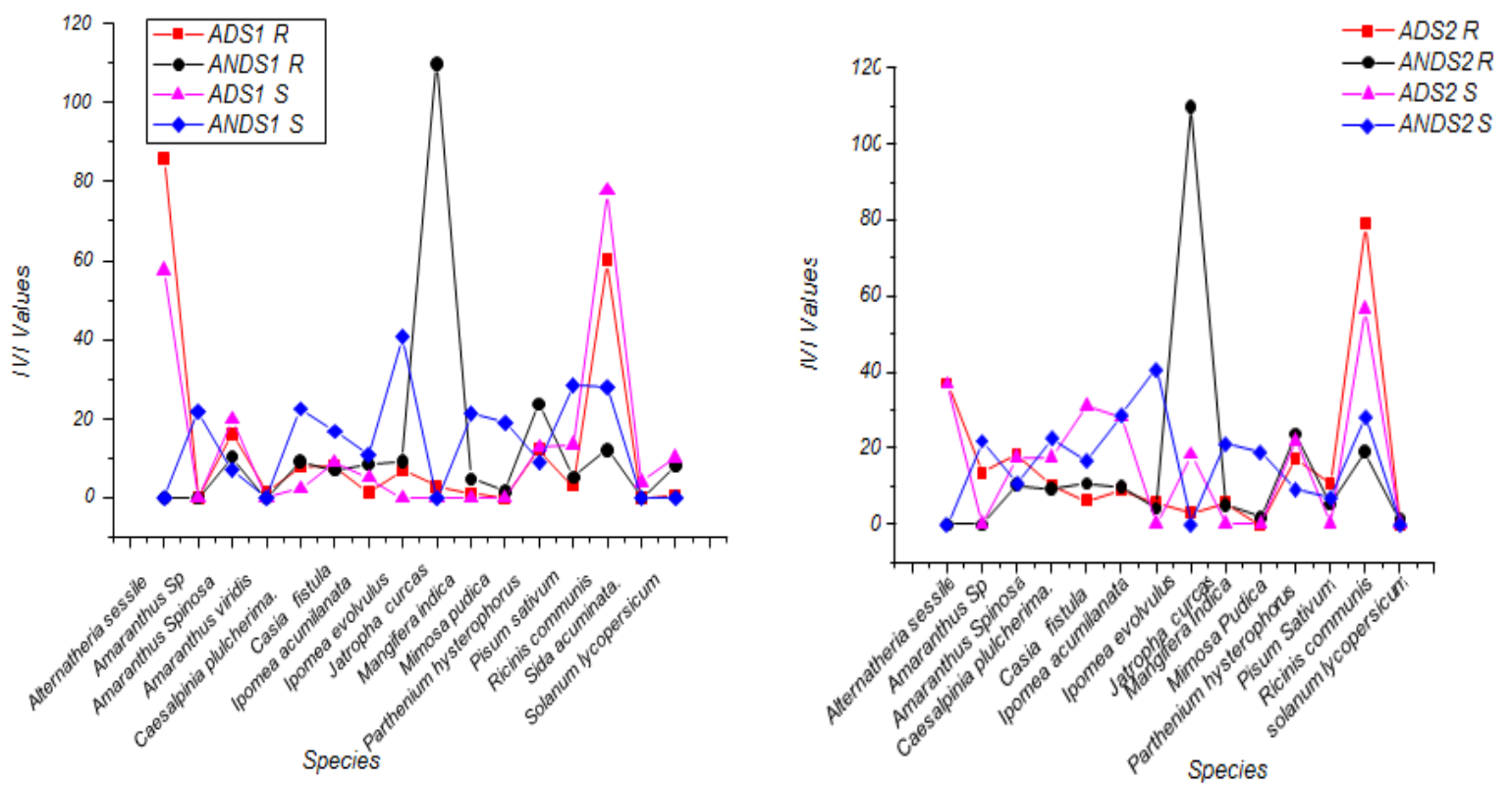

Fig. 9 IVI values of vegetations at (a) Agara dumpsite 1 in the spring and summer seasons (ADS1R and ADS1S, respectively), and non-dumpsite 1 in the spring and summer seasons (ANDS1 $R$ and ANDS1 $S$, respectively), (b) Agara dumpsite 2 in the spring and
summer seasons (ADS2R and ADS2S, respectively) and non-dumpsite 2 in the spring and summer seasons (ANDS2 R and ANDS2 $S$, respectively) 


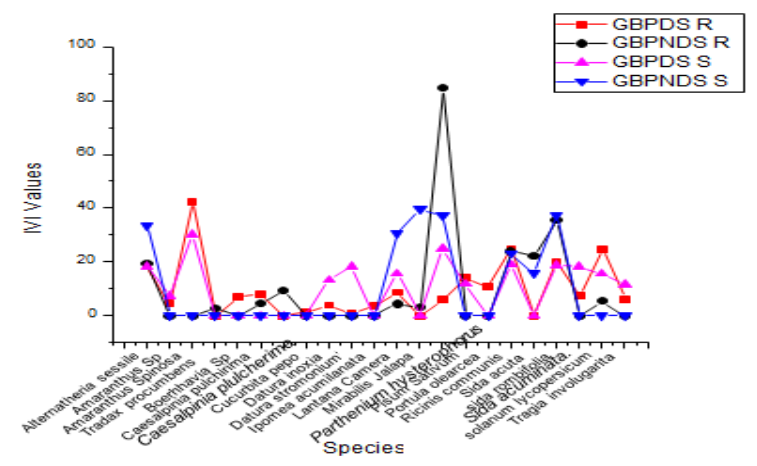

Fig. $10 \mathrm{IVI}$ values of vegetation at GB Palya dump site in the spring and summer seasons (GBPDS $R$ and GBPDS S, respectively), and GB Palya nondumpsites in the spring and summer seasons (GBPNDS R and GBPNDS S, respectively)

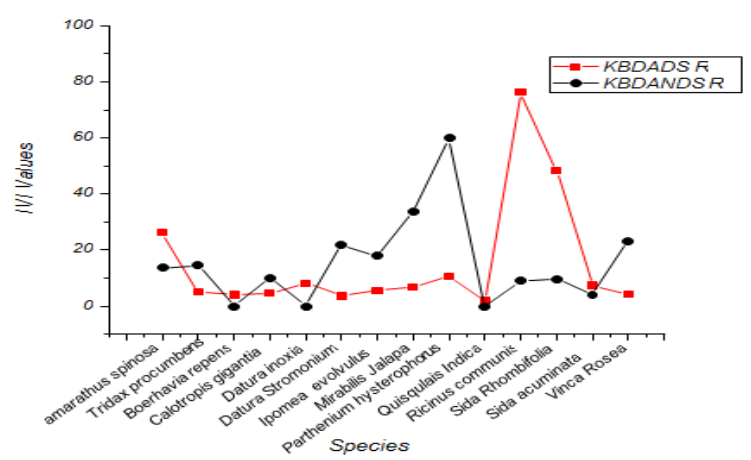

Fig. 12 IVI values of Koramangala BDA dumpsite and non-dumpsite in spring season (KBDADS $R$ and KBDANDS $R$, respectively)

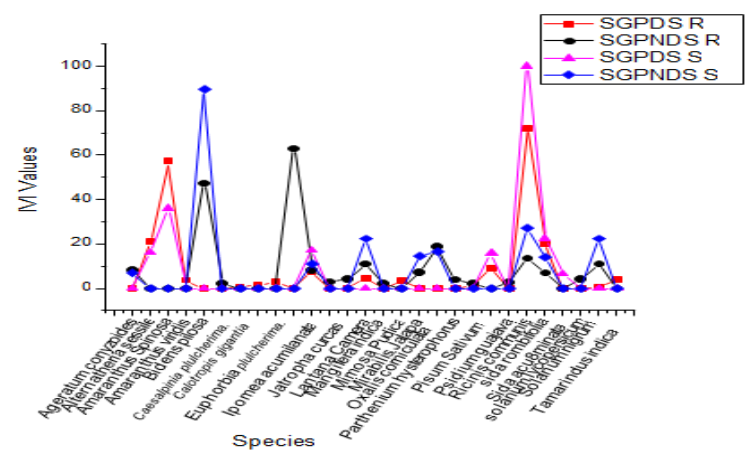

Fig. 14 IVI values of SG Palya dumpsite spring and summer seasons (SGPDS $R$ and SGPDS S, respectively), and non-dumpsite in spring and summer seasons (SGPNDS R and SGPNDS S, respectively)

Soil analysis: Table 2 represents the mean values of the physicochemical characteristics of the soil of both dump and non-dumpsites across all locations while Fig 2-8 represents the same in each location.

In general, dumpsites with leachate of wastes are characterized by high concentrations of organic and inorganic pollutants (Calli 2005). The organic and inorganic pollutants alter the $\mathrm{pH}$ and thereby electrical conductivity of soil due to the presence

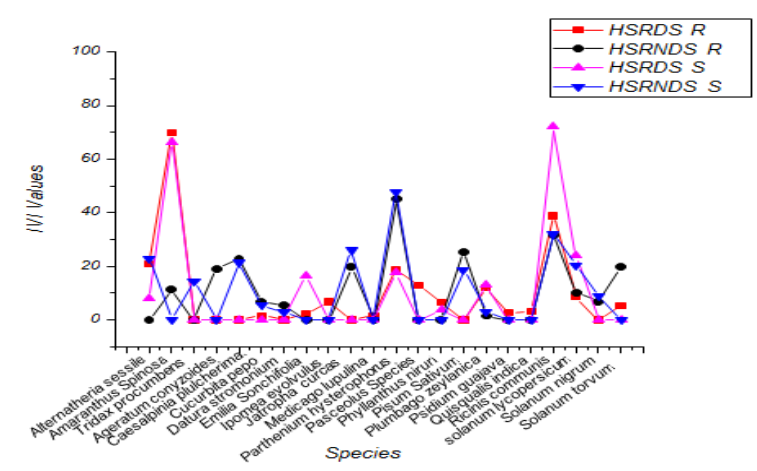

Fig. 11 IVI values of HSR Depo dumpsite in spring and summer seasons (HSRDS R and HSRDS S, respectively), and non-dumpsite in spring and summer seasons (HSRNDS R and HSRNDS S, respectively)

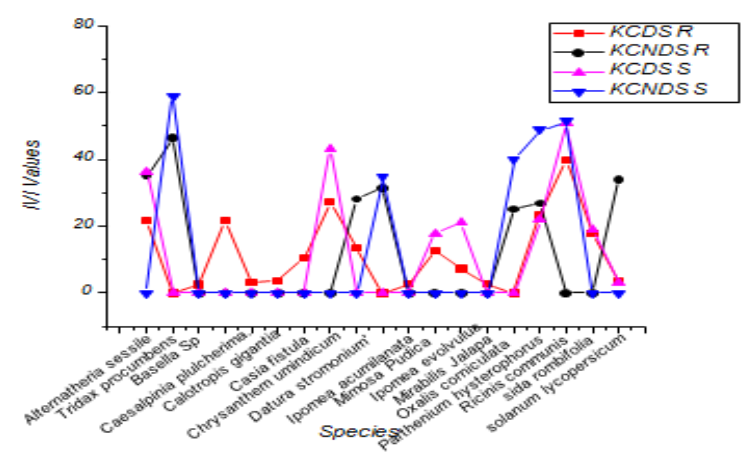

Fig. 13 IVI values of Koramangala Church dumpsite in spring and summer seasons (KCDS R and KCDS $S$, respectively), and non-dumpsite in spring and summer seasons (KCNDS R and KCNDS S, respectively)

of salts. In the present study, the soil $\mathrm{pH}$ of dump site was more alkaline $(8.04 \pm 0.21)$ than that of non -dumpsites $(7.71 \pm 0.22)$ The alkaline $\mathrm{pH}$ is very often observed at surrounding waste disposal sites aging 10 years (El-Fadel 2002). Significant amount of bicarbonate is produced during biodegradation process of organic matter which collectively results into the increase in the soil $\mathrm{pH}$ (Mahapatra 2011). Alteration in soil pH can affect the survival of plants and slightly acidic $\mathrm{pH}$ increases the nutrient uptake in plants. Alkaline $\mathrm{pH}$ often reduces the nutrient uptake in plants. The electrical conductivity of the soil of dump sites was found to be 1.5-fold higher than the nondumpsites (Table 2). The high electrical conductivity in the dump sites may be attributed to the discharge of leachates loaded with the dissolved salts of sodium and magnesium (Pillai et al., 2014).

Total soluble solute, alkalinity and chloride content showed a decrease of $20 \%, 12.68 \%$ and 17.05 $\%$, respectively in the dumpsites as compared to the non-dumpsites (Table 2) Minerals such as nitrogen, nitrates, potassium, phosphorous, sulphates, sodium, calcium and magnesium content 


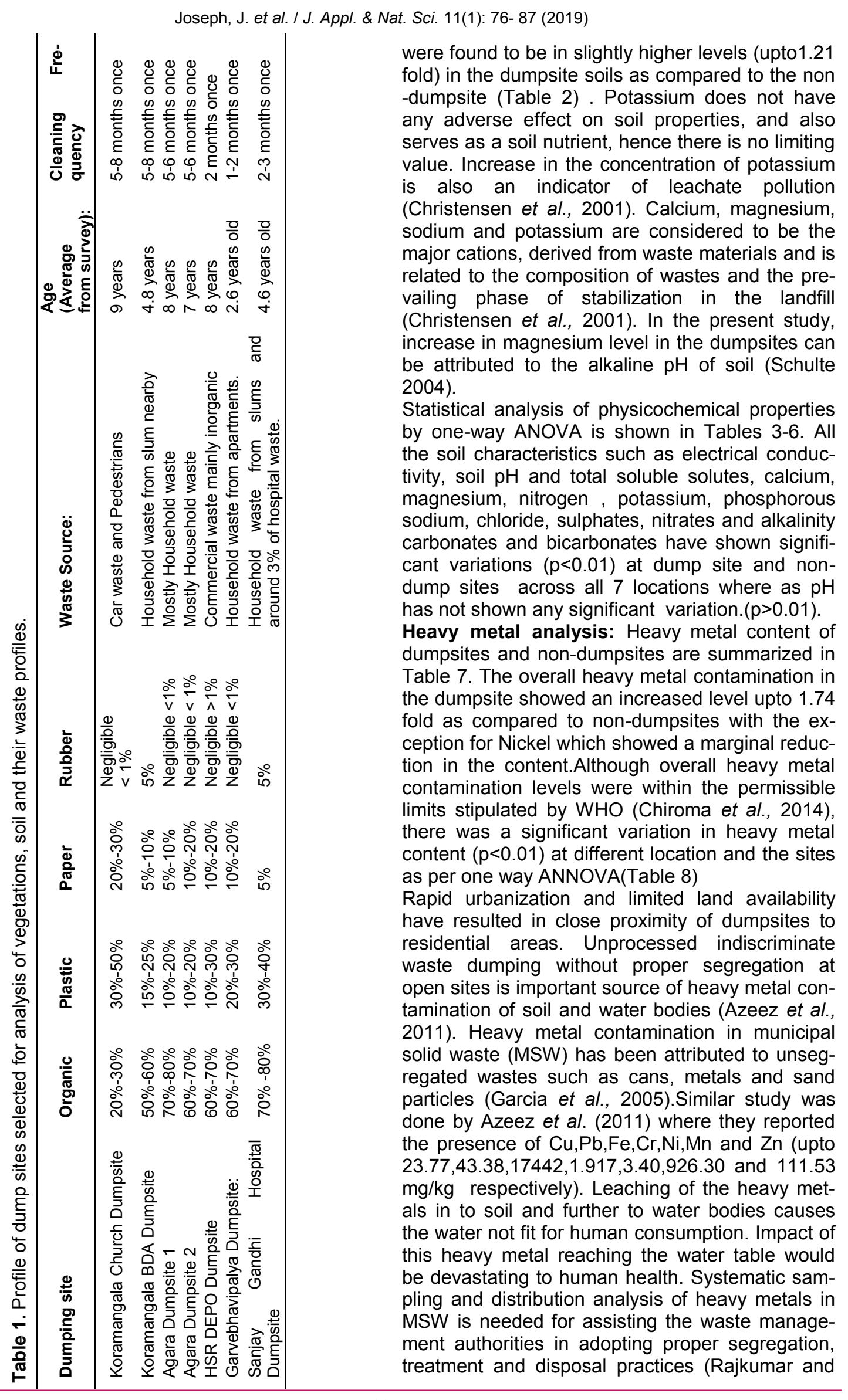


Table 2. Physicochemical properties of soil from dump and non-dumpsites across all locations.

\begin{tabular}{lllll}
\hline Parameters & \multicolumn{2}{c}{$\begin{array}{l}\text { Non-dump sites } \\
\text { (Mean } \pm \text { SD) }\end{array}$} & \multicolumn{3}{c}{$\begin{array}{l}\text { Dumpsites } \\
\text { (Mean } \pm \text { SD) }\end{array}$} \\
\hline Electrical Conductivity $(\mu \mathrm{mho} / \mathrm{cm})$ & 305.43 & \pm 79.12 & 478.071 & \pm 257.64 \\
pH & 7.71 & \pm 0.22 & 8.04 & \pm 0.21 \\
Total Soluble Solutes $(\% \mathrm{w} / \mathrm{w})$ & 0.05 & \pm 0.04 & 0.04 & \pm 0.01 \\
Alkalinity Carbonates and Bicarbonates $\left(\mathrm{CaCO}_{3} \mathrm{mg} / \mathrm{kg}\right)$ & 1363.00 & \pm 209.36 & 1190.14 & \pm 425.40 \\
Chloride $(\mathrm{mg} / \mathrm{kg})$ & 806.79 & \pm 239.17 & 669.21 & \pm 160.61 \\
Calcium $(\mathrm{mg} / \mathrm{kg})$ & 1321.00 & \pm 397.15 & 1602.14 & \pm 409.61 \\
Magnesium $(\mathrm{mg} / \mathrm{kg})$ & 789.86 & \pm 241.55 & 913.29 & \pm 282.20 \\
Nitrates $(\mathrm{mg} / \mathrm{kg})$ & 25.28 & \pm 11.44 & 25.88 & \pm 11.24 \\
Nitrogen $(\mathrm{mg} / \mathrm{kg})$ & 65.65 & \pm 22.44 & 76.13 & \pm 9.29 \\
Phosphorous $(\mathrm{mg} / \mathrm{kg})$ & 19.58 & \pm 9.33 & 20.72 & \pm 9.82 \\
Potassium $(\mathrm{mg} / \mathrm{kg})$ & 54.63 & \pm 17.86 & 62.22 & \pm 9.81 \\
Sodium $(\mathrm{mg} / \mathrm{kg})$ & 346.07 & \pm 138.36 & 368.71 & \pm 88.37 \\
Sulphates $(\mathrm{mg} / \mathrm{kg})$ & 110.90 & \pm 29.39 & 118.07 & \pm 25.14 \\
\hline
\end{tabular}

Table 3. ANOVA for soil physical properties across location over dump and non-dumpsites.

\begin{tabular}{lllcl}
\hline \multirow{2}{*}{ Source of variation } & \multirow{2}{*}{$\boldsymbol{f} \boldsymbol{f}$} & \multicolumn{3}{c}{ F Statistic } \\
\cline { 3 - 5 } & & Electrical Conductivity & Soil pH & Total Soluble Solutes \\
\hline Location & 6 & $1270.182^{* *}$ & 1.257 & 0.329 \\
Site & 1 & $3824.891^{* *}$ & 3.614 & $5.025^{\star}$ \\
Location $\times$ Site & 6 & $584.539^{* *}$ & 0.838 & 0.329 \\
\hline
\end{tabular}

The values are which are significant at 0.05 and 0.01 levels, have ${ }^{*}$ for 0.05 and ${ }^{* *}$ for 0.01 as superscripts.

The values without superscripts are differently significant.

Table 4. ANOVA for calcium, magnesium, total nitrogen and phosphorus across location over dump and nondumpsites.

\begin{tabular}{lllllll}
\hline \multirow{2}{*}{ Source of variation } & \multirow{2}{*}{$\boldsymbol{d f}$} & \multicolumn{5}{c}{ F Statistic } \\
\cline { 3 - 7 } & & Calcium & Magnesium & Nitrogen & Potassium & Phosphorous \\
\hline Location & 6 & $292.851^{* *}$ & $1014.950^{* *}$ & $1019.314^{\star *}$ & $276.196^{\star *}$ & $51.946^{* *}$ \\
Site & 1 & $643.712^{* *}$ & $604.354^{* *}$ & $1136.529^{* *}$ & $157.243^{\star *}$ & 0.663 \\
Location $\times$ Site & 6 & $261.809^{* *}$ & $1176.792^{* *}$ & $943.549^{* *}$ & $152.414^{* *}$ & $23.809^{* *}$ \\
\hline
\end{tabular}

The values are which are significant at 0.05 and 0.01 levels, have ${ }^{*}$ for 0.05 and ${ }^{* *}$ for 0.01 as superscripts. The values without superscripts are differently significant.

Table 5. ANOVA for sodium, chloride, sulphate, nitrate and alkalinity-cabrobates and bicarbonate across location over dump and non-dumpsites.

\begin{tabular}{llllllll}
\hline $\begin{array}{l}\text { Source } \\
\text { variation }\end{array}$ & of & df & & \multicolumn{5}{c}{ F Statistic } \\
\cline { 4 - 7 } & & Sodium & Chloride & Sulphates & Nitrates & $\begin{array}{l}\text { Alkalinity Carbonates and } \\
\text { Bicarbonates }\end{array}$ \\
\hline $\begin{array}{l}\text { Location } \\
\text { Site }\end{array}$ & 6 & $51.037^{* *}$ & $128.363^{* *}$ & $100.097^{* *}$ & $371.864^{* *}$ & $317.732^{* *}$ \\
$\begin{array}{l}\text { Location } \\
\text { Site }\end{array}$ & $\times$ & 6 & $12.052^{* *}$ & $320.326^{* *}$ & $9.204^{* *}$ & $11.864^{* *}$ & $153.862^{* *}$ \\
\hline
\end{tabular}

The values are which are significant at 0.05 and 0.01 levels, have * for 0.05 and ${ }^{* *}$ for 0.01 as superscripts. The values without superscripts are differently significant.

Table 6. ANOVA for soil characteristics across location at dumpsite and non-dumpsites.

\begin{tabular}{|c|c|c|c|}
\hline Across locations & $d f$ & & \\
\hline Soil traits & $\boldsymbol{d t}$ & Non-dumpsite & Dumpsite \\
\hline Electrical Conductivity & 6 & $121.551^{\star \star}$ & $2557.062^{* *}$ \\
\hline & 6 & 0.809 & $4.867^{*}$ \\
\hline Total Soluble Solutes & 6 & $20.695^{\star *}$ & $219.773^{\star *}$ \\
\hline Calcium & 6 & $317.815^{\star *}$ & $246.672^{\star \star}$ \\
\hline Magnesium & 6 & $4254.260^{* *}$ & $681.797^{\star *}$ \\
\hline Nitrogen & 6 & $1170.740^{* *}$ & $384.284^{\star *}$ \\
\hline Potassium & 6 & $262.301^{* *}$ & $139.095^{\star *}$ \\
\hline Phosphorous & 6 & $25.686^{* *}$ & $63.771^{* *}$ \\
\hline Sodium & 6 & $139.697^{* *}$ & $63.655^{\star *}$ \\
\hline Chloride & 6 & $340.412^{* *}$ & $241.467^{* *}$ \\
\hline Sulphates & 6 & $144.073^{* *}$ & $38.115^{\star *}$ \\
\hline Nitrates & 6 & $283.385^{\star *}$ & $325.196^{* *}$ \\
\hline Alkalinity carbonates and bicarbonates & 6 & $65.632^{* *}$ & $422.413^{\star *}$ \\
\hline
\end{tabular}

The values are which are significant at 0.05 and 0.01 levels, have ${ }^{*}$ for 0.05 and ${ }^{* *}$ for 0.01 as superscripts. The values without superscripts are differently significant. 


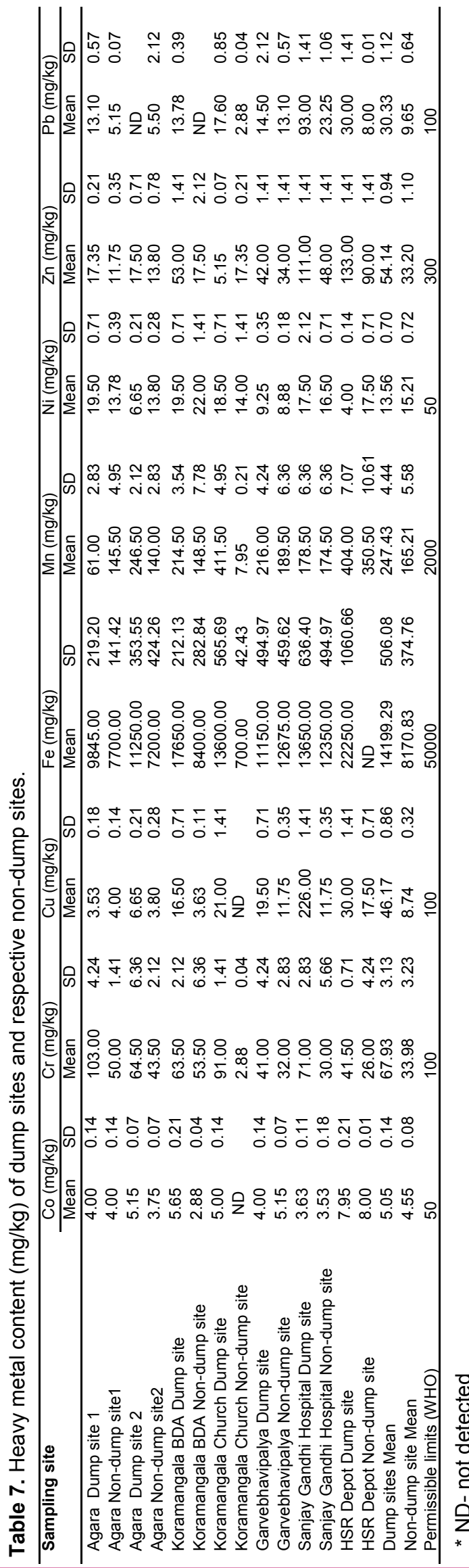

Sirajuddin 2016).

Vegetation analysis: IVI values of the plants growing in various dumpsites and non-dumpsites are shown in Figs. 9-14. The dominant species obtained from evaluation of common plant species growing in both dumpsite and non-dumpsites are shown in Tables 9 and 10, respectively. ANOVA was performed for the comparison of various consistent plants growing in both non-dumpsites and dumpsites (Table 11).

Although 50 different plant species were noticed across different locations during the study period. (Table 9 and 10) only 13 species were found in common across non-dumpsites (Table 9), while in the dumpsites the common species number was reduced to 6 (Table 10). This can be attributed to the soil contamination in the dumpsites (Syeda et al., 2013). Putting together the above 19 species, ten species such as Alternatheria sessile, Amaranthus spinose, Caesalpinia pulcherima, Ipomea acumilanata, Ipomea evolvulus, Parthenium hysterophorus, Pisum sativum, Ricinis communis, Sida rombifolia and Solanum lycopersicum were consistent across the sites as well as the locations during the study period. Hence, only these species datasets were taken into consideration for the analysis of variance Table 11 ( $a$ and $b$ ) represents ANOVA statistics for dominance of different plant species found across various locations of dump and non-dumpsites for two seasons.

A. spinosa, C. pulcherima, I. acumilanata, P. hysterophorus, $P$. sativum and $S$. rhombifolia showed significant variation $(0.001 \leq p \leq 0.05)$ which indicates there is a difference in dominance of these species across locations. Most of the species showed no significant variation for sites (Dump and non-dumpsites) across all 7 locations except A. spinosa, $P$. sativum and $S$. rhombifolia which designates there was a difference in the dominance of these 3 species between dumpsite and the non-dump sites. All the species, except $I$. acumilanata, did not show any significant variation for the two seasons (i.e. spring and summer) which specifies the season doesn't have any effect on the dominance of these species. Except $S$. rombifolia, $A$. spinosa and $P$. sativum, rest of the species did not show any significant variation in dominance for location and sites when considered together as sources of variation whereas none of the species varied significantly in dominance across the sites as well as seasons. While considering both location and sites as sources of variation most of the species showed non-significant variation in dominance except $I$. acumilanata and $P$. sativum.

Altered soil composition and soil physicochemical properties between dumpsite and non-dumpsite makes the difference in botanical species diversity and growth. Changes in the physicochemical profile of the soil alter the soil fertility, providing a se- 
Joseph, J. et al. / J. Appl. \& Nat. Sci. 11(1): 76- 87 (2019)

Table 8. ANOVA of heavy metal content over dumpsite and non-dumpsites.

\begin{tabular}{|c|c|c|c|c|c|c|c|c|c|}
\hline \multirow{2}{*}{$\begin{array}{l}\text { Source of varia- } \\
\text { tion }\end{array}$} & \multirow{2}{*}{$d f$} & \multicolumn{8}{|c|}{ F Statistic } \\
\hline & & $\mathrm{Cr}$ & Co & $\mathbf{P b}$ & $\mathrm{Cu}$ & $\mathrm{Fe}$ & Mn & $\mathrm{Ni}$ & $\mathrm{Zn}$ \\
\hline Location & 6 & $61.03^{\star *}$ & $499.96^{\star *}$ & $1578.46^{\star *}$ & $11937.56^{\star *}$ & $374.19^{\star *}$ & $839.62^{* \star}$ & $93.024^{* *}$ & $4212.056^{\star *}$ \\
\hline Site & 1 & $550.43^{* *}$ & $197.92^{* *}$ & $3163.13^{\star *}$ & $18058.27^{* *}$ & $458.81^{* *}$ & $1409.65^{\star *}$ & $23.053^{* *}$ & 2284.500 ** \\
\hline Location $\times$ Site & 6 & $63.15^{\star \star}$ & $107.16^{* *}$ & $655.52^{* *}$ & $10767.48^{* *}$ & $106.19^{\star *}$ & $717.17^{\star *}$ & $55.572^{* *}$ & $506.449^{\star *}$ \\
\hline
\end{tabular}

The values are which are significant at 0.05 and 0.01 levels, have ${ }^{*}$ for 0.05 and ${ }^{* *}$ for 0.01 as superscripts. The values without superscripts are differently significant.

Table 9. Classification of species dominance at non-dump sites during spring and summer season.

\begin{tabular}{llll}
\hline Rainy & IVI values & Summer & IVI values \\
\hline Jatropha curcus & 109.77 & Bidens pilosa & 89.53 \\
Parthenium hysterophorus & 84.80 & Tridax procumbens & 59.15 \\
Euphorbia pulcherima & 63.07 & Ricinis communis & 51.52 \\
Parthenium sp. & 59.97 & Parthenium hysterophorus & 48.86 \\
Bidens pilosa & 47.45 & Ipomea evolvulus & 40.78 \\
Tridax procumbens & 46.61 & Oxalis corniculata & 40.15 \\
Sida rombifolia & 35.54 & Mirabilis jalapa & 39.60 \\
Alternatheria sessile & 35.34 & Sida rombifolia & 37.32 \\
Solanum lycopersicum & 33.96 & Datura stromonium' & 34.91 \\
Mirabilis jalapa & 33.81 & Alternatheria sessile & 33.40 \\
Ricinis communis & 31.90 & Lantana camera & 30.68 \\
Datura stramonium & 28.16 & Ipomea acumilanata & 28.75 \\
Pisum sativum & 25.37 & Pisum sativum & 28.75 \\
Oxalis corniculata & 25.21 & Jatropha curcus & 26.05 \\
Vinca rosea & 23.02 & Caesalpinia pulcherima & 22.64 \\
Caesalpinia pulcherima & 22.84 & Solanum nigrum & 22.40 \\
Sida acuta & 22.12 & Amaranthus sp & 21.88 \\
Datura inoxia & 21.89 & Mangifera indica & 21.25 \\
Solanum nigrum & 19.73 & solanum lycopersicum & 20.41 \\
Ageratum conyzoides & 19.10 & Mimosa pudica & 19.10 \\
\hline
\end{tabular}

Table 10. Classification of species dominance at dump site during spring and summer season.

\begin{tabular}{llll}
\hline Rainy & IVI values & Summer & IVI values \\
\hline Alternatheria sessile & 85.84 & Ricinis communis & 99.84 \\
Ricinis communis & 79.01 & Amaranthus spinosa & 66.36 \\
Amaranthus spinosa & 69.87 & Alternatheria sessile & 57.60 \\
Sida rhombifolia & 48.38 & Chrysanthemum indicum & 43.15 \\
Chrysanthemum indicum & 27.23 & Casia fistula & 31.08 \\
Solanum lycopersicum & 24.65 & Ipomea acumilanata & 28.10 \\
Parthenium hysterophorus & 23.26 & Parthenium hysterophorus & 24.92 \\
Caesalpinia pulcherima. & 21.72 & Solanum lycopersicum & 23.94 \\
Pisum sativum & 14.11 & Sida rombifolia & 22.37 \\
Amaranthus sps & 13.65 & Mimosa pudica & 21.12 \\
Datura stramonium & 13.58 & Jatropha curcus & 18.44 \\
Phasceolus vulgaris & 12.89 & Datura stromonium' & 18.35 \\
Ipomea evolvulus & 12.74 & Sida accuminata & 18.25 \\
Plumbago zeylanica & 11.95 & Ipomea evolvulus & 17.89 \\
Portula olearcea & 10.79 & Caesalpinia pulcherima & 17.53 \\
Casia fistula & 10.51 & Eupotorium sps & 17.12 \\
Pisum Sp. & 9.23 & Emilia sonchifolia & 16.43 \\
Ipomea acumilanata & 9.22 & Pisum Sp & 15.97 \\
Lantana camera & 8.73 & Lantana camera & 15.58 \\
Datura inoxia & 8.18 & Pisum sativum & 13.45 \\
\hline
\end{tabular}

lective environment for specific vegetation adaptive to the altered soil condition.

Diversity of plant species was recorded with seasonal variations at both dumpsite and non-dump site. Analysis of ecological indices such as IVI provides a better understanding of species dominance and community structure of vegetation at dump sites. Tripathi and Misra (2011) studied the vegetation associated with physicochemical variation at dumpsites and the corresponding nondumpsites in Allahabad city in India. By analysis of ecological indices of species found at study sites, adaptive dominant plants were identified out of 32 species identified at dump sites. They identified that Nepeta hindostana, R. communis, Lantana camara and Calotrophis procera as the dominant 
Table 11.(a). ANOVA of consistent species namely Alternathera sessile, Amaranthus spinose, Caesalpinia sp., Ipomea acumilanata, Ipomea evolvulus.

\begin{tabular}{lllllll}
\hline Source of variation & $\boldsymbol{d f}$ & $\begin{array}{l}\text { Alternathera } \\
\text { sessile }\end{array}$ & $\begin{array}{l}\text { Amaranthus } \\
\text { spinosa }\end{array}$ & $\begin{array}{l}\text { Caesalpinia } \\
\text { pulcherima }\end{array}$ & $\begin{array}{l}\text { Ipomea } \\
\text { acumilanata }\end{array}$ & $\begin{array}{l}\text { Ipomea } \\
\text { evolvulus }\end{array}$ \\
\hline Location & 6 & 1.89 & $10.97^{* *}$ & $6.43^{*}$ & $119.09^{* *}$ & 1.41 \\
Site & 1 & $10.60^{*}$ & $53.85^{* *}$ & $8.43^{*}$ & 2.41 & 1.92 \\
Season & 1 & 0.71 & 0.68 & 0.29 & $31.13^{* *}$ & 1.09 \\
Location $\times$ Site & 6 & 2.67 & $8.14^{*}$ & 3.10 & 4.65 & 1.68 \\
Site $\times$ Season & 1 & 0.01 & 0.34 & 0.66 & 0.10 & 2.56 \\
Location $\times$ Season & 5 & 0.62 & 1.17 & 1.24 & $41.13^{* *}$ & 0.52 \\
\hline
\end{tabular}

** Significance at $1 \%$; * Significance at $5 \%$; df: degrees of freedom

Table 11. (b). ANOVA of consistent species namely Parthenium hysterophorus., Pisum sativum, Ricinis communis, Sida rombifolia and Solanum lycopersicum, over dump site and non-dump sites across locations during spring and summer season.

\begin{tabular}{lllllll}
\hline Source of variation & $\boldsymbol{d f}$ & $\begin{array}{l}\text { Parthenium } \\
\text { hysterophorus }\end{array}$ & $\begin{array}{l}\text { Pisum } \\
\text { sativum }\end{array}$ & $\begin{array}{l}\text { Ricinis } \\
\text { communis }\end{array}$ & $\begin{array}{l}\text { Sida } \\
\text { rombifolia }\end{array}$ & $\begin{array}{l}\text { Solanum } \\
\text { lycopersicum }\end{array}$ \\
\hline Location & 6 & $7.17^{*}$ & $5.76^{*}$ & 2.02 & $246.26^{* *}$ & 3.19 \\
Site & 1 & $22.28^{* *}$ & 2.64 & $44.90^{* *}$ & $91.06^{* *}$ & 0.18 \\
Season & 1 & 0.05 & 0.01 & 4.96 & 3.72 & 0.76 \\
Location $\times$ Site & 6 & 2.97 & $7.90^{*}$ & 2.90 & $68.54^{* *}$ & 1.84 \\
Site $\times$ Season & 1 & 0.65 & 2.14 & 0.17 & 0.12 & 3.03 \\
Location $\times$ Season & 5 & 0.65 & $5.11^{*}$ & 1.11 & 1.30 & 2.10 \\
\hline
\end{tabular}

** Significance at $1 \%$; * Significance at $5 \%$; df: degrees of freedom

species adapted to the dumpsites analyzed. In our study, the ecological indices of vegetation across seven dumpsites and during two diverse seasonal variations (spring and summer) were analysed. In the present study based on the IVI value of vegetation across seven dumpsites, $A$. sessile, $R$. communis and $A$. spinosa were identified as the dominant species which have wider adaptability to thrive at dumpsites at diverse seasonal variations.

\section{Conclusion}

In consideration with all soil characteristics such as soil physical properties (electrical conductivity, soil $\mathrm{pH}$ and total soluble solutes), soil nutrients (calcium, magnesium, nitrogen and potassium, phosphorus, sodium, chloride, sulphates, nitrates and alkalinity carbonates and bicarbonates) as well as the heavy metals (Co, $\mathrm{Cr}, \mathrm{Cu}, \mathrm{Fe}, \mathrm{Mn}, \mathrm{Ni}$, $\mathrm{Zn}$ and $\mathrm{Pb}$ ), it is concluded that the dumping of unprocessed municipal wastes alters the physicochemical profile of soil significantly. Changes in the physicochemical profile of the soil further alter the soil fertility, providing a selective environment for specific vegetation adaptive to the altered soil condition. As far as vegetation analysis, 10 species viz Alternatheria sessile, Amaranthus spinose, Caesalpinia pulcherima, Ipomea acumilanata, Ipomea evolvulus, Parthenium hysterophorous Pisum sativum, Ricinis communis, Sida rombifolia and Solanum lycopersicum were found consistent across all locations irrespective of the seasons. Among these, $A$. sessile, R. communis and $A$. spinosa were found dominant across seven locations. As these plants were found thriving across locations withstanding the waste dumping flux, they can be explored further for their ability to phy- toremediate the land pollutants especially the heavy metals.

\section{ACKNOWLEDGEMENTS}

Authors are thankful to Centre for Research, CHRIST (Deemed to be University), Bengaluru, India, for the financial assistance (F. No. MNGDSC1503) towards this research. JJ and DS are also thankful to the Head of the Department of Life Sciences, CHRIST (Deemed to be University) Bengaluru, India, for supporting this research in terms of Laboratory space and equipment.

\section{REFERENCES}

1. Angaye, T. C. N., Zige, D. V., and Izah, S. C. (2015). Microbial load and heavy metal properties of leachate from solid waste dump site in the Niger Delta, Nigeria. Journal of Environmental Treatment Techniques, 3(5), 71-75.

2. Azeez, J. O., Hassan, O. A., and Egunjobi, P. O. (2011). Soil contamination at dump sites: implication of soil heavy metals distribution in municipal solid waste disposal system: a case study of Abeokuta, South-western Nigeria. Soil and Sediment Contamination, 20(4), 370-386.

3. Calli, B., Mertoglu, B., and Inanc, B. (2005). Landfill leachate management in Istanbul: applications and alternatives. Chemosphere, 59, 819-829.

4. Chiroma, T. M., Ebewele, R. O., and Hymore, F. K. (2014). Comparative assessment of heavy metal levels in soil, vegetables and urban grey waste water used for irrigation in Yola and Kano. International Refereed Journal of Engineering and Science, 3(2):19

5. Christensen, T.H., Kjeldsen, P., Bjerg, P.L., Jensen, D.L., Christensen, J.B., and Heron, G. (2001). Biogeochemistry of landfill leachate plumes. Applied Geochemistry, 16(7-8), 659-718. 
6. DAC. (2011). Methods and manual soil testing in India. Department of Agriculture and Cooperation, Ministry of Agriculture, Government of India, New Delhi, India.

7. El-Fadel, M., Bou-Zeid, E., Chahine, W., and Alayli B. (2002) Temporal variation of leachate quality from pre-sorted and baled municipal solid waste with high organic and moisture content. Waste Management, 22, 269-282.

8. Garcıa, A. J., Esteban, M. B., M'arquez, M. C., and Ramos, P. (2005). Biodegradable municipal solid waste: characterization and potential use as animal feedstuffs. Waste Management, 25, 780-787.

9. Kent, M. (2011). Vegetation description and data analysis: a practical approach. USA: John Wiley and Sons.

10.Mahapatra, D.M., Chanakya, H.N., and Ramachandra, T.V. (2011). Role of macrophytes in sewage fed urban lake. Institute of Integrative Omics and Applied Biotechnology Journal, 2(8), 1-9.

11.Nagendran, R. A., Selvam, K. J., and Chart, C. (2006). Phytoremediation and rehabilitation of municipal solid waste landfills and dump sites: A brief review. Waste Management, 26, 1357-1369,

12. Opaluwa, O. D., Aremu, M. O., Ogbo, L. O., Abiola K. A., et al., (2012). Heavy metal concentrations in soils, plant leaves and crops grown around dump sites in Lafia Metropolis, Nasarawa State, Nigeria. Advances in Applied Science Research, 3(2):780784

13.Pattnaik, S., and Reddy, M.V., (2010). Assessment of municipal solid waste management in Puducherry (Pondicherry), India. Resources Conservation and Recycling, 54, 512-520.

14.Pillai, S., Peter, A.E., Sunil, B.M., and Shrihari, S. (2014). Soil pollution near a municipal solid waste disposal site in India. International Conference on Biological, Civil and Environmental Engineering. 148152. http://dx.doi.org/10.15242/IICBE.C0314080
15.Rajkumar, J., and Sirajuddin, A. (2016). Status and challenges of municipal solid waste management in India: a review. Cogent Environmental Science, 2(1), 1139434.

16.Schulte, E.E. (2004). Soil and applied magnesium. In A2524 Understanding Soil Nutrients. University of Wisconsin-Madison USA. http://www.soils.wisc.edu/ extension/pubs/A2524

17.Singh, R.P., Singh, P., Arouja, A. S. F., Ibrahim, M.H., and Sulaiman, O. (2011). Management of urban solid waste: vermicomposting a sustainable option. Resources, Conservation and Recycling, 55, 719-729.

18.Sudhir, V., Muraleedharan, V. R., and Srinivasan, G. (1996). Integrated solid waste management in Urban India: A critical operational research framework. Socio Economic Planning Sciences, 30, 163-181.

19.Syeda, M. A., Pervaiz, A., Afzal, B., Hamid, N., and Yasmin, A. (2014). Open dumping of municipal solid waste and its hazardous impacts on soil and vegetation diversity at waste dumping sites of Islamabad city. Journal of King Saud University Science, 26:5965

20.Tripathi A., Misra D.R., (2012), Floral distributions at municipal waste dumpsites in relation to their soil properties: Identification of adaptive plants. Bulletin of Environmental and Scientific Research, 1: (2), 1-10.

21.USDA. (2011). Soil quality indicator: soil electrical conductivity. Natural Resources Conservation Services, USA

22.USEPA. (1983). Inductively Coupled Plasma Atomic Emission Spectrometric method for trace element analysis of water and waste - method 200.7.

23.Zennaro, M., Cristofori, F., Formigoni, D., Frignani, F., and Pavoni, B. (2005). Heavy metal contamination in compost. A possible solution. Annali di Chimica, 95, 247-256. 